\title{
Learning styles and learning approaches: How closely are they associated with each other and do they change during medical education?
}

\author{
Öğrenme stilleri ve öğrenme yaklaşımları: Birbirleri ile ilişkili mi ve tıp eğitimi sırasında \\ değişiyor mu?
}

Ayşe Hilal BATI, Nilüfer Demiral YILMAZ, Tahir YAĞDI

\begin{abstract}
Objectives: This study aims to determine medical students' learning styles and approaches and to evaluate the relationship between them, as well as observe whether any changes occur in these during the course of their education.

Methods and Materials: This research was carried out on students who were enrolled in 2008-2009 and was conducted in their first, second and fourth years. The study group consisted of students who had fully completed the scales of measurement used for this research in all years. Learning styles and approaches were determined for each period.

Results: An increase in the convergent and divergent styles and a decrease in the assimilator style, determined over the years were not statistically significant. The decline in the deep learning approach scores was important. Evaluating the relationship between the learning styles and approaches, we found that the deep learning approach scores with the divergent style were lower in the first two years; however, no relationship was observed in the fourth year.

Conclusions: The learning style follow-up study indicates a trend among students who will try to understand the whole by giving importance to details, to focus on problem solving, and to move away from traditional learning. The decrease in deep learning approaches may be linked to the nature of assignments and testing systems.
\end{abstract}

Keywords: Learning, Learning styles, Learning approaches, Undergraduate medical education

\footnotetext{
Ayşe Hilal Batı (ه), Nilüfer Demiral Yılmaz

Department of Medical Education, School of Medicine, Ege University, Izmir, Turkey

e-mail:hilal.bati@ege.edu.tr

Tahir Yağdı

Department of Cardiothoracic Surgery, School of Medicine, Ege University, Izmir, Turkey
}

Öz

Amaç: Araştırmanın amacı, Ege Üniversitesi Tıp Fakültesi öğrencilerinin eğitim süreçlerinde öğrenme stil ve yaklaşımlarının belirlenmesi ve öğrenme stilleri ile öğrenme yaklaşımları arasındaki ilişkinin değerlendirilmesidir.

Gereç ve Yöntem: Araştırma, 2008-2009 akademik y1lında Ege Üniversitesi Tıp Fakültesinde eğitime başlayan öğrencilerin eğitimlerinin 1., 2. ve 4. yıllarında gerçekleştirilmiştir. Araştırmada kullanılan ölçekleri üç akademik yılda da eksiksiz olarak dolduran ögrenciler araştırma grubunu oluşturmuştur. Öğrencilerin her dönemdeki öğrenme stilleri ve öğrenme yaklaşımları belirlenmiştir.

Bulgular: Öğrencilerin ilerleyen eğitim yıllarında belirlenen, ayrıştıran ve değiştiren öğrenme stillerindeki artış ve özümseyen stildeki azalma istatistiksel önem taşımamaktadır. Öğrencilerin yıllar içinde derin öğrenme yaklaşım puanlarındaki azalma önemlidir. Öğrenme stilleri ile öğrenme yaklaşımları arasındaki ilişki değerlendirildiğinde ilk iki yılda değiștiren öğrenme stiline sahip öğrencilerin derin yaklaşım puanlarının daha düşük olduğu, 4. yılda ise öğrenme stil ve yaklaşımları arasında ilişki olmadığ saptanmıştır.

Sonuç: Ege Üniversitesi Tıp Fakültesi öğrencilerinin üç farklı dönemdeki öğrenme stili izlemleri, detayları önemseyerek bütünü anlamaya çalışan, sorun çözümüne yönelen, geleneksel öğrenmeden uzaklaşan bir yönelimi işaret etmektedir. Derin öğrenme yaklaşımlarındaki azalma sınav sistemine bağlanabilir.

Anahtar kelimeler: Öğrenme, Öğrenme stilleri, Öğrenme yakaşımları, Mezuniyet öncesi tıp eğitimi 


\section{Introduction}

The ever-growing burden of information and the need to change and update this information mean that educational programs have become highly intensive. Under this burden, students tend towards memorizing rather than learning, and as a result, they graduate before having acquired the tools necessary for them to learn how to learn, or having gained an adequate grasp of the philosophy of lifelong learning. To solve these problems, the aim should be to train students in such a way that they learn how to learn, and acknowledge responsibility for self-learning. Hence, it is crucial that individuals should recognize their own learning characteristics and approaches, strengths and weaknesses.

There is a general consensus that the way individuals approach a learning situation is an influence in reaching performance and learning outcomes [1]. The learning style and learning approach that define the learning characteristics of individuals are two different concepts in close proximity to each other, which gain meaning when they are defined and known together. If they are used in a relevant manner by educators and students, they will lead to a more efficient learning process. The terms learning styles and learning approaches are generally used interchangeably. Although they are similar, these two concepts differ on many levels. While learning style indicates the ways in which the learner deals with the reception and processing of information, learning approach defines the method preferred by the learner as he or she is addressing a learning task [2].

Every human being uses different and unique ways of preparing, learning and remembering new information and this is referred to as a learning style $[3,4]$. Learning styles do not depend on the learning ability of the learners and do not determine how to improve learning ability [2].

The learning model is defined from two perspectives, as functioning at the comprehensive level (concrete experiences and abstract conceptualization) and at the conversion level (reflective observation and active experimentation). This is an ideal learning process in which the learner functions on a feeling, monitoring, thinking and doing basis, and in which he or she questions the process of learning and what is learnt [5]. Kolb describes the learning styles of the individuals according to these learning methods in four groups $[6,7]$ :

Assimilators: In this style the individuals consider their educators as the most important source of information. They are internalizing individuals with a tendency to learn by listening and watching and prefer to receive systematic information that has been structured in a sequential, logical and detailed manner.

Convergers: The individuals who have a convergent learning style are good at issues such as systematic planning and deductive reasoning. These individuals, who try to understand the whole by giving importance to details, learn by doing and thinking, and they are more successful in tests where there is only one answer.

Divergers: These individuals, who are patient and learn carefully, prefer to deal with technical issues and problems rather than with social and interpersonal issues. Their tendencies to learn by doing and feeling enable them to look at tangible situations from different angles, to make observations in the face of events, and to focus on situations presenting different ideas.

Accommodators: These individuals, who make use of their previous experience in the learning process, welcome new practices and experiences. In problem solving, they prefer to use information derived from others rather than analyzing and thinking.

No matter what the learning style is, an evaluation of it as good or bad is not under discussion here. Individuals adopt a learning style appropriate to the learning context. In the educational field, learning styles are used as a means of developing the application of teaching methods and structures; however, they are not an indicator of the ability of the individual to understand content and context.

The learning processes were first classified by Marton and Saljo in 1976 at two basic levels, as superficial and deepprocessing. Later, the term "approach" was put forward by Enwistle et al., in 1979 in order to identify the differences in these two learning methods. Unlike learning styles, learning approach is linked with the level of understanding of the learner rather than his or her way of comprehending and processing the information. The quality and quantity of learning is determined by the learning approach adopted by the student. The learning approach consists of a motivationstrategy set that comprises the strategies adopted by students to attain the motivation and learning objectives that are necesssary to achieve the desired learning outcome $[8,9]$. Motivation indicates why the students want to learn, whereas strategy indicates how they learn [10].

It is known that learning approach is affected by many factors, such as the characteristics of the teaching, the intensity of the educational program, the nature of the educational environment, testing methods and 
teaching methods $[11,12]$. Learning approaches measure the relationship between two conscious and deliberate approaches of the student in order to understand the content and context for a learning task. The level of understanding and exact learning appear as a result of the approach chosen for learning [2]. The learning approach indicates the harmony between the purpose, motivation and learning strategy of the students [13].

In the literature, three learning approaches are described as superficial, deep and strategic:

Deep approach: The students try to associate new information related to the learning topic with what has already been learnt, use the evidence and make logical evaluations. They examine the different aspects of the material in order to see the whole picture, and explore the points of connection between daily life and personal experience $[9,13]$.

Superficial approach: The students tend to choose the fastest way to achieve success. They prefer learning by memorizing without understanding, without asking detailed questions, by studying in a linear form and by dealing with the subject at the minimal level [14].

Strategic approach: This is an approach in which students display purpose and motivation in order to be successful and achieve the highest possible grades by effectively organizing their time and the learning environment. A strategic approach can be combined with deep or superficial learning approaches [13]. It has emerged as a term that defines students who have the ability to adopt both the deep and superficial learning approaches. Those students who are academically more successful adopt a strategic or performance-oriented approach [2]. Kember et al., in 1999 have reported that the learning approaches of students can be described with a model consisting of two main factors. Each main factor has a strategy indicator characterised principally by the presence or absence of the intention to understand the material. [15].

The ever-growing importance of lifelong learning and individual learning requires the recognition and development of concepts such as learning styles and approaches. While some researchers and educators believe that learning styles are of a nature that is flexible and more amenable to change depending on the learning environment, others maintain that they are difficult to change. [16]. Kolb argued that the learning styles of individuals are not constant and may change over time [6]. The learning style of each individual is in a relatively stable structure in accordance with their personal characteristics, and displays compliance with learning status [2]. The learning approaches considered as a reaction to the learning environment, however, are dynamic and open to change [17-19]. Learning approach may change with prior knowledge, capabilities, educational program (together with measurement-evaluation, course structure and content), teaching methods, the learning climate of learning and learning outputs [20]. There is evidence indicating that the deep learning approach can be taught and developed through education and practice $[8,17]$.

The purpose of this study is to determine the learning styles and approaches of the students at Ege University, Faculty of Medicine, where an integrated education model is implemented, to investigate the change in subsequent educational periods, and furthermore, to determine whether or not there is a relationship between the learning styles and learning approaches.

The questions that will be attempted to be answered by this research are as follows;

1. What are the learning styles and approaches of the students who were enrolled at Ege University, Faculty of Medicine in the academic year 2008-2009?

2. Is there a change in the learning styles and approaches of the students in the ensuing years of education?

3. Is there a meaningful relationship between the learning styles and approaches of the students?

\section{Materials and Methods}

\section{Study Group}

This research was carried out by following the 354 students who started their education at Ege University, Faculty of Medicine, in the academic year 2008-2009 during the course of their educational process. In the first year, the status of the students was determined prior to undergoing medical education; in the second and fourth years, however, their status was monitored at pre-clinical and clinical stages. The educational program of Ege University, Faculty of Medicine has been carried out by providing vertical integration in the first three years since the academic year 2003-2004 after the horizontal integration practice that started in 1997, and in the fourth and fifth years as from the academic year 20112012. The educational program incorporates horizontal and vertical integration arranged with a spiral approach, aimed at 
graduation targets and covering the priority health issues of the community. At Ege University, Medical Faculty, organsystem based themes in ten blocks are formed by many different disciplines in the first three years. Additionally, in these blocks, small group activities and simulated patient problem sessions are implemented. The students here are assessed by questions requiring short answers in each block and by multiple-choice question (MCQ), simulated patient problems, assignments and a portfolio at the end of each block. Similarly, six clinical internship blocks are formed by many different disciplines in the fourth and fifth years. The students here are assessed by MCQ and oral exams at the end of each block.

In this follow-up research conducted with ethical approval, it was aimed to reach all of the students in each year without determining a sample.

\section{Instruments}

In the literature, different scales are used in studies researching the learning styles and approaches of medical faculty students. In the determination of the learning style, it is in particular the Kolb Learning Style Inventory which is more commonly used $[3,7]$.

One of the scales used most frequently in the evaluation of the learning approaches is the Approaches to Study Inventory (ASI) developed by the Lancaster group, and the Revised Approaches to Study Inventory (RASI), the revised form of ASI. Another, however, is the Study Process Questionnaire (SPQ) developed by Biggs. This scale was later reviewed, and its short and final form Revised Two Factor Study Process Questionnaire (R-SPQ-2F) was devised $[9,21]$. Apart from these, there are also scales that contain many articles, and that make multi-dimensional measurements. In this type of scale, easy applicability gains importance because answering takes a long time, participation in the survey is low and not all of the articles are answered. The measurement tools chosen for this research on the grounds of common usage and easy applicability are defined below:

1. Kolb Learning Style Inventory: The Kolb Learning Style Inventory which was adapted to Turkish and whose validity and reliability study was conducted by Aşkar and Akkoyunlu has been used to determine the learning styles [3]. In this scale with 12 questions, each of which contains four subordinate clauses, there are 48 subordinate clauses in total. For each question, the students' responses are scored in a way that will allot 4 points to the statement that suits them the best of the four subordinate clauses, and 1 to the statement that suits them the least. The results ranging between -36 and +36 obtained in the calculation made with this scoring are evaluated in the diagram developed by Kolb, and the learning styles are determined.

\section{Revised Two Factor Study Process Questionnaire:} Learning approaches were evaluated by using the new form of the R-SPQ-2F developed by Biggs and adapted to our language. The validity- reliability study was conducted by Bati et al. [9]. The R-SPQ-2F is a refined version of Biggs' original SPQ. It consists of 20 items scored on a five-point Likert scale and categorizes the students into two different approaches to learning (surface and deep), each with a motive and strategy. The scale point that can be taken for deep and superficial approach is between $10-50$ points [21].

3. Survey form: A short questionnaire form consisting of independent variables (gender, class attended, choosing to study at the Faculty of Medicine of his/her own will, etc.) considered to have affected the learning styles and approaches of the students, was only applied in the first year of the research because the same students were monitored.

The scales were applied in the academic years 20082009, 2009-2010 and 2011-2012 by means of a single form.

\section{Data Analysis}

The data were evaluated by using the Statistical Package for Social Science (SPSS) version 21.0. Chi-square, McNemar, ANOVA and variance analysis in the repeated measurements tests were used in the statistical analyses.

\section{Results}

Three hundred and fifty-four students were attending the first year class in 2008. The scales used in the research were completed in full by $319(90.1 \%), 228$ (64.4\%), and 178 $(50.3 \%)$ of them in the academic years 2008-2009, 20092010 and 2011-2012 respectively. Monitoring was possible for the 154 (43.5\%) students who completed these scales in full in all three years.

It was determined that $49.4 \%$ (76) of the students comprising the study group were females and that $94.8 \%$ (146) had chosen the medical faculty of their own will.

When the students' learning styles were examined, the rate of students adopting the assimilator and converter 
learning styles in all three years was higher. While this rate decreased relatively in the fourth year, the increase in the rate of the students with a diverger learning style attracted attention. The change of learning styles between the educational periods presented in Table I does not bear any statistical importance $\left(\mathcal{X}^{2}{ }_{\text {Mc Nemar-Bowker }}: 2.452, P: 0.874\right)$.

A meaningful relationship was not detected between gender and learning styles in any of the three educational periods. When the students' free choice of the faculty and their learning styles were compared, however, the relationship between choosing the faculty of their own will and the assimilator learning style was found to be meaningful only in the first year $\left(\mathrm{X}^{2}: 8.288, P: 0.040\right)$.

When the educational periods and the learning approach scores of the students were compared, while their superficial approaches did not change, it was observed that there was a decrease in their deep learning approaches over the years. It was found that the group that created a difference with Post Hoc LSD analysis were the first year students (Table II).
When an evaluation was made according to the components of the deep learning approach scores, it was seen that there was a statistically meaningful decrease in both the deep motivation (F:10.825, P:0.000) and deep strategy (F:17.549, $P: 0.000)$ scores. It was determined that the difference with Post Hoc LSD analysis resulted from the first year students.

When the students' free choice of the profession and the effect of their gender on learning approach were examined, the superficial approach scores of the students who were males and who did not choose the profession willingly were higher in all the educational periods. When the learning approach scores in the three years were examined in terms of gender, a difference between the deep approach scores of the female and male students was not detected. In spite of this, the superficial approach scores of the male students were found to be higher than those of female students at a meaningful level. This difference arose from the superficial motivation scores. While the deep approach scores did not

Table I. The learning styles of the research group according to the educational periods

\begin{tabular}{|c|c|c|c|c|c|c|c|c|c|c|c|}
\hline \multirow[b]{3}{*}{ Period } & \multicolumn{11}{|c|}{ Learning Styles (n:154) } \\
\hline & \multicolumn{2}{|c|}{ Assimilator } & \multicolumn{2}{|c|}{ Converger } & \multicolumn{2}{|c|}{ Diverger } & \multicolumn{2}{|c|}{ Accommodator } & \multicolumn{3}{|c|}{ Statistical Analysis* } \\
\hline & $\mathbf{n}$ & $\%$ & $\mathbf{n}$ & $\%$ & n & $\%$ & $\mathbf{n}$ & $\%$ & & $x^{2}$ & $P$ \\
\hline 1st & 87 & 56.6 & 48 & 31.2 & 9 & 5.8 & 10 & 6.5 & 1-2 year & 7.994 & 0.239 \\
\hline 2nd & 77 & 50.0 & 58 & 37.7 & 9 & 5.8 & 10 & 6.5 & 1-4 year & 6.876 & 0.332 \\
\hline 4th & 71 & 46.1 & 60 & 39.0 & 14 & 9.1 & 9 & 5.8 & 2-4 year & 2.452 & 0.874 \\
\hline
\end{tabular}

$* \boldsymbol{x}^{2} \mathrm{Mc}$ Nemar-Bowker

Table II. The learning approach of the study group according to educational period

\begin{tabular}{|c|c|c|c|c|}
\hline \multirow{3}{*}{ Period } & \multicolumn{4}{|c|}{ Learning Approach Mean Scores (n:154) } \\
\hline & \multicolumn{2}{|c|}{ Deep Approach } & \multicolumn{2}{|c|}{ Surface Approach } \\
\hline & Mean & SD & Mean & SD \\
\hline 1st & 32.05 & 5.513 & 27.14 & 6.416 \\
\hline 2nd & 30.45 & 6.461 & 27.20 & 7.148 \\
\hline 4th & 29.33 & 6.003 & 26.97 & 6.562 \\
\hline \multirow{2}{*}{ Statistical Analysis * } & \multicolumn{2}{|c|}{ F 17.768} & \multicolumn{2}{|c|}{0.094} \\
\hline & \multicolumn{2}{|c|}{$P 0.000^{*}$} & \multicolumn{2}{|c|}{0.910} \\
\hline
\end{tabular}

* ANOVA for repeated-measures $P<0.05$ and Post Hoc LSD $P<0.05$, the group that created the difference 1 st Year 
display any difference in the first year in terms of freely choosing the profession, it was found to be higher in those who chose the profession freely in the second and fourth years. The high superficial approach level of the scores of those who did not freely choose the profession, however, created a statistical difference in all three years.

When the relationship between the learning styles and learning approaches was evaluated, it was detected that the deep approach (F: 3.047, $P$ : 0.031) and deep motivation (F.2.950, $P: 0.035$ ) scores of the students with a diverger learning style were lower than those of students favouring another learning style in the first two periods. In the Post Hoc evaluation, the group that created a difference was determined to be the students with a diverger learning style. In the second year, in addition to this, in the Post Hoc analysis, it was found that the deep approach scores of the students who had a converger learning style were higher than in the other groups, whilst their superficial approach scores were lower (Table III).

In the fourth year, the number of students who had an assimilator and converger learning style was high and equal in both of the learning approaches. Despite this, the deep or superficial approach score averages of the students in terms of their learning styles did not display a statistical difference (Table IV).

\section{Discussion}

The profession of medicine, which must be engaged in with enthusiasm and devotion, necessitates the constant renewal of acquired knowledge together with lifelong learning, due to an ever-growing information load, even after a long and challenging educational process. No matter how

Table III. The relationship between gender, free choice of the profession and learning approaches

\begin{tabular}{|c|c|c|c|c|c|c|c|c|c|}
\hline \multirow{2}{*}{ Period } & \multirow{2}{*}{$\begin{array}{l}\text { Learning } \\
\text { Approach }\end{array}$} & \multicolumn{2}{|c|}{ Gender } & \multicolumn{2}{|c|}{ Statistical Analysis* } & \multicolumn{2}{|c|}{$\begin{array}{c}\text { Choosing the Profession } \\
\text { Willingly }\end{array}$} & \multicolumn{2}{|c|}{$\begin{array}{l}\text { Statistical } \\
\text { Analysis * }\end{array}$} \\
\hline & & Female (76) & Male (78) & $\mathrm{t}$ & $P$ & Yes (146) & No (8) & $\mathrm{t}$ & $P$ \\
\hline \multirow{2}{*}{ 1st } & Deep & $32.37 \pm 5.54$ & $31.74 \pm 5.51$ & 0.702 & 0.484 & $32.15 \pm 5.44$ & $30.25 \pm 6.86$ & 0.949 & 0.344 \\
\hline & Surface & $25.53 \pm 5.38$ & $28.72 \pm 6.97$ & -3.177 & 0.002 & $26.75 \pm 6.19$ & $34.38 \pm 6.55$ & -3.384 & 0.001 \\
\hline \multirow{2}{*}{ 2nd } & Deep & $30.71 \pm 6.03$ & $30.19 \pm 6.88$ & 0.496 & 0.620 & $30.69 \pm 6.37$ & $26.00 \pm 6.93$ & 2.020 & 0.045 \\
\hline & Surface & $25.97 \pm 6.50$ & $28.40 \pm 7.58$ & -2.128 & 0.035 & $26.87 \pm 6.92$ & $33.25 \pm 9.05$ & -2.500 & 0.013 \\
\hline \multirow{2}{*}{ 4th } & Deep & $29.30 \pm 5.82$ & $29.36 \pm 6.22$ & 0.292 & 0.954 & $29.60 \pm 5.99$ & $24.50 \pm 3.96$ & 2.373 & 0.019 \\
\hline & Surface & $25.40 \pm 5.94$ & $28.47 \pm 6.83$ & -2.946 & 0.004 & $26.71 \pm 6.31$ & $31.75 \pm 9.47$ & -2.139 & 0.034 \\
\hline
\end{tabular}

*Student's t test

Table IV. The relationship between learning approaches and learning styles

\begin{tabular}{|c|c|c|c|c|c|c|c|c|c|c|c|c|c|c|c|}
\hline \multirow{3}{*}{ Period } & \multirow{3}{*}{$\begin{array}{l}\text { Learning } \\
\text { Approach }\end{array}$} & \multicolumn{12}{|c|}{ Learning Style } & \multirow{2}{*}{\multicolumn{2}{|c|}{$\begin{array}{l}\text { Statistical } \\
\text { Analysis* }\end{array}$}} \\
\hline & & \multicolumn{3}{|c|}{ Assimilator } & \multicolumn{3}{|c|}{ Converger } & \multicolumn{3}{|c|}{ Diverger } & \multicolumn{3}{|c|}{ Accommodator } & & \\
\hline & & $\mathrm{N}$ & Mean & $\mathrm{SD}$ & $\mathrm{N}$ & Mean & SD & $\mathrm{N}$ & Mean & $\mathrm{SD}$ & $\mathrm{N}$ & Mean & $\mathrm{SD}$ & $\mathrm{F}$ & $P$ \\
\hline \multirow{2}{*}{$1 \mathrm{st}$} & Deep & 87 & 32.33 & 5.22 & 48 & 32.50 & 5.50 & 9 & 26.78 & 7.26 & 10 & 32.20 & 4.69 & 3.047 & 0.031 \\
\hline & Surface & 87 & 26.62 & 5.98 & 48 & 27.02 & 6.89 & 9 & 32.22 & 5.95 & 10 & 27.70 & 7.09 & 2.150 & 0.096 \\
\hline \multirow{2}{*}{ 2nd } & Deep & 77 & 29.16 & 5.95 & 58 & 32.60 & 5.99 & 9 & 27.00 & 7.65 & 10 & 31.00 & 8.64 & 4.322 & 0.006 \\
\hline & Surface & 77 & 28.94 & 6.70 & 58 & 24.50 & 6.57 & 9 & 29.78 & 6.46 & 10 & 27.20 & 9.96 & 5.030 & 0.002 \\
\hline \multirow{2}{*}{ 4th } & Deep & 71 & 29.37 & 5.69 & 60 & 29.97 & 6.32 & 14 & 26.93 & 5.48 & 9 & 28.56 & 7.14 & 1.023 & 0.384 \\
\hline & Surface & 71 & 26.52 & 6.86 & 60 & 26.27 & 6.28 & 14 & 30.21 & 5.52 & 9 & 30.22 & 5.89 & 2.274 & 0.082 \\
\hline
\end{tabular}

*ANOVA $P<0.05$, Post Hoc LSD $P<0.05$, Difference is created by the students who have a learning style undergoing change in the first two years. 
heavy the professional workload is in the process of work, access to new information becomes a part of life. Hence, the continuity of education is achieved with self-directed learning in which individuals undertake responsibility for their own learning. The awareness of individuals regarding their own learning styles bears special importance with regard to maintaining more efficient learning in the process of education and working life. It is known that learning styles and approaches stem from individual preference, and can change with factors such as learning environments, tasks, and test systems. The educational program which is carried out through multidisciplinary integration at Ege University, Faculty of Medicine, supports students' learning and constitutes a basis for future learning. In this study, which evaluates the learning characteristics of the students in the educational process in our Faculty, remarkable results have been achieved.

The learning style follow-ups of the students at our medical faculty during three different periods indicated a tendency amongst them of trying to understand the whole by giving importance to detail, of moving towards problem solving, and away from traditional learning.

In this study, in line with the researches carried out previously in Turkey and a research study in Sri Lanka, a decline in the deep learning approaches in the process was detected [14, 22-24]. It was thought that this change could be connected to the tasks/assignments in the process of education and the nature of the testing systems. In the study of Samarakon et al., however, it was determined that there was no difference between the first and final years in terms of learning approaches [25]. In the qualitative study of Ozolins et al., it was determined that the students used informal sources such as previous exam questions, the lecture notes of previous students, and the interviews carried out with them while they were preparing for the exams. The students underlined the fact that they obtained information to pass exams in a way that did not fit with their learning approach in the educational process, and that they were prepared for the exams with more superficial learning [26]. The change that we detected in the deep learning approach was supported by other studies which determined that students channel their learning towards exam performance in an effort to use their time efficiently as a consequence of highly intensive educational programs and workload concerns [27]. The decrease in the deep approaches of the students with a diverger learning style emphasized the problem-oriented approaches of these students. It can be said that because the learning styles do not display any change in the first three years, the density of theoretical knowledge that constitutes the basis for their professional education in the first years of the faculty playes a crucial role in the students' maintenance of learning styles adopted during the period of secondary education.

In our faculty, more time is allocated to professionoriented practical training and given more space in the educational program especially in the second year. Besides this, the ever-increasing density of information and the lengthy courses, as with all medical faculties, present challenges in the use of time for students at an individual level. These factors can explain the decrease of students favouring the assimilator and converger learning styles and also the tendency of those using the diverger learning style to reduce the use of information for solving a particular problem.

Given the fact that learning approaches can change as a result of factors such as preliminary information, skills, educational program, teaching methods, learning climate or learning outcomes, the decrease in the deep approach scores of medical faculty students seems more understandable $[8,12,28]$. Medical faculty students come from secondary education institutions where different teaching approaches are applied, and they endeavour to adapt to the educational structure, environment and program of the faculty. The elevation of the deep approach level in this period depends on the level of intrinsic motivation [23]. Especially in the first year of faculty, students combine the topics that constitute a basis for professional education with their previously acquired learning styles and try to prepare for the clinical process. On the one hand, the students who enter the faculty with a high level of success after a stressful university entrance examination period must adapt to a challenging professional educational process, and on the other, they aim to maintain the high levels of success achieved. The regression in the motivation determining why students want to learn and strategy indicating how they learn outside the dimensions of deep learning approaches also indicates a the tendency to aim to succeed in mastering intensive learning topics in a short time. Lawson reported that Newstead stated in the research he conducted that frequency of formal measurement assessment may cause superficial learning [23]. Smith and Miller's study results indicated that assessment type had no significant influence on how students approached their learning [29]. Gijbels et al., also reported that the learning 
approaches of the students might change depending on the assessment method that was used. They emphasized the fact that assessment was not a practice applied at the end of the learning process or a practice that was separate from education, but was a powerful tool that stimulated deep learning [30]. In spite of the fact that the presence of the formative interim assessments in the evaluation system in our faculty supports the learning process, it leads students to feel that they are subject to too many exams in addition to the already loaded content of education. For this reason, it is feasible that they opt for the superficial learning approach on a strategic basis and largely prefer to memorize most of the time in order to be successful. Learning, teaching and assessment integration bears a special importance. Besides this, it was emphasized that the other learning environment features such as the work load, feedback, regular and segmented information which affected the learning approaches of the students should also be taken into consideration [30].

In this research, whilst no relationship was determined between gender and learning styles and deep approach points in all three educational periods, it was found that the superficial approach scores of male students were found to be significantly higher than those of female students. In spite of the fact that the relationship between gender and learning approach was not among the purposes of this research, it was evaluated in the light of the data obtained. In the literature, there was no consistency between the results found in the studies addressing this issue. In Wickramasinghe and Samarasekera's study, it was determined that learning approaches were similar in both sexes, and that the male students preferred to obtain information via an instructor support, whilst the female students preferred to obtain information passively [18]. Similarly, the relationship between learning approach and gender had not been established in Shah's study [31]. In the researches of Duff, Gledhill and Van Der Merwe, it was reported that the deep approach scores of the female students were high in accordance with our research; however, Sadler-Smith's results were completely the opposite. Apart from these, results had been reported in many research studies as to the fact that gender was not a determinant $[32,33]$. In different sources, there were views to the effect that these inconsistent results could be affected by many factors such as statistical analysis, cultural differences and learning environments [19,34]. Carrying out qualitative studies would shed more light in order to be able to interpret the results.
Choosing or not choosing the profession willingly is a determinative factor for motivation. In this research, the fact that the students who did not choose the profession willingly had a higher superficial score in all the periods, can be explained by the fact that these students perceived this educational period as a duty to be completed, and that they adopted a superficial motivation with the goal of merely completing this task successfully.

The fact that the deep approach scores of students with a converger learning style were higher than those of the other groups and that their superficial approach scores were lower in the second year was compatible with the analytical and objective approaches of converger students and their characteristic of giving importance to detail. Thus it was an expected result.

Despite the fact that the deep or superficial approach scores of the students did not differ in the fourth year in terms of their learning styles, the number of students with an assimilator and converger learning style was high for both learning approaches. The number of students with an assimilator learning style was high in each period, can be considered as an outcome of the primary and secondary education system in our country. No matter to what extent the complex structure of medical education affects the learning characteristics of the individuals, the intensive educational process and time restrictions lead students to a superficial approach which is more simplistic. In addition to this, concern for the Specialty Exam in Medicine that must be passed after graduation and is carried out via a centralized system, is a significant factor in students developing a superficial learning approach that focuses on this exam, consisting as it does of MCQ. In spite of these issues, the relative increase in the number of students with a converger learning style in our faculty can be evaluated as an outcome of the laboratory and practical training which play an extensive role in our educational program.

This study was essential in that it was a piece of research in which learning styles and approaches were assessed with a three-year follow-up and a high answer rate. On the other hand, it had two basic limitations. The first of these was that several very important confounding factors such as educational program and learning environment features, assessment methods and teaching characteristics had been ignored because the research was carried out only on the students in a medical faculty. The second limitation was that the social factors regarding the students such as place of accommodation, family-friend features, were left out of 
the assessment during the follow-up. It would be beneficial to answer these research questions in medical faculties adopting a different educational program model with qualitative research that pays regard to the limitations that we have mentioned.

\section{Conclusions}

Learning styles and approaches play an important role in the learning process. Determination of the learning styles and approaches of medical students is helpful in evaluating teaching and assessment-evaluation strategies. This can enable favorable changes to be made to improve medical education programs as well as giving support in particular to students experiencing academic difficulties.

The effect of the educational environment on shaping the learning characteristics of students is observed in this research as well as in many other studies. The applications that support life-long and self-directed learning are particularly vital in structuring medical education programs. Students should be encouraged to use their learning approaches over a wide range in order to strengthen their cognitive skills and individual development. For this purpose, it would be useful to develop student-centered applications as well as supporting the measurement and evaluation systems in a way that would motivate learning.

\section{References}

1. Topal K, Sarikaya O, Basturk R, Buke A. Marmara Med J 2015;28:81-9. doi: 10.5472/MMJ oa .2802. 04

2. Tsingos C, Bosnic-Anticevich S, Smith L. Learning styles and approaches: Can reflective strategies encourage deep learning? Curr Pharm Teach Learn 2015;4:492-504. doi: 10.1016/j.cptl.2015.04.006

3. Aşkar P, Akkoyunlu B. Kolb ögrenme stili envanteri. Egitim ve Bilim 1993;87:37-47.

4. Dunn R, Giannitti M, Murray J, Rossi I, Geisert G, Quinn P. Grouping students for instruction: effects of learning style on achievement and attitudes. J Soc Psychol 1990;130:485-94. doi: 10.1080/00224545.1990.9924610

5. Kolb A, Kolb D. The learning way. Meta-cognitive aspects of experiential learning. Simulation \& Gaming 2009;40:297327. doi: $10.1177 / 1046878108325713$

6. Gurpinar E, Bati H, Tetik C. Learning styles of medical students change in relation to time. Advan Physiol Edu 2011;35:307-11. doi: 10.1152/advan.00047.2011

7. Kolb A, Kolb D. The Kolb Learning Style Inventory Version 3.1. Cleveland, $\mathrm{OH}$ : Case Western Reserve Univ, USA: Technical Specifications, 2005.
8. Biggs J. Learning strategies, student motivation patterns, and subjectively perceived success In: Kirby JR, ed. $1^{\text {ST }}$ ed. Cognitive Strategies and Educational Performance. Orlando Fla: Academic Press, 1984.

9. Batı A, Tetik C, Gurpınar E. Öğrenme yaklaşımları ölçeği yeni şeklinin Türkçe'ye uyarlama ve geçerlik güvenirlik çalışması. Turkiye Klinikleri J Med Sci 2010;30:1639-46. doi: 10.5336/medsci.2009-15368

10. Zhang L, Sternberg R. Are learning approaches and thinking styles related? A study in two Chinese populations. J Psychol 2000;134:469-89. doi: 10.1080/00223980009598230

11. Newble D, Entwistle N. Learning styles and approaches: implications for medical education. Med Educ 1986;20:16275. doi: 10.1111/j.1365-2923.1986.tb01163.x

12. Salamonson $\mathrm{Y}$, Weaver R, Chang S, K, et al. Learning approaches as predictors of academic performance in first year health and science students. Nurse Education Today 2013;33:729-33. doi: 10.1016/j.nedt.2013.01.013

13. Diseth A. The Relationship between intelligence, approaches to learning and academic achievement. Scandinav Edu Res 2002;46:219-30. doi: 10.1080/00313830220142218

14. Aharony N. The use of deep and surface learning strategies among students learning English as a foreign language in an Internet environment. Br J Educ Psychol 2006;76(Pt4):85166. doi: 10.1348/000709905X79158

15. Kember D, Wong A, Leung D. Reconsidering the dimensions of approaches to learning. Br J Educ Psychol 1999;69:32343. doi: 10.1348/000709999157752

16. Murray-Harvey R. Learning styles and approaches to learning: distinguishing between concepts and instruments. Br J Educ Psychol 1994;64:373-88. doi: 10.1111/j.20448279.1994.tb01110.x

17. Azer S, Guerrero A, Walsh A. Enhancing learning approaches: Practical tips for students and teachers. Medical Teacher 2013;35:433-43. doi: 10.3109/0142159X.2013.775413

18. Wickramasinghe D, Samarasekera D. Factors influencing the approaches to studying of preclinical and clinical students and postgraduate trainees. BMC Medical Education 2011a;11(22). doi: 10.1186/1472-6920-11-22

19. Zeegers P. Approaches to learning in science: A longitudinal study. Br J Educ Psychol 2001;71:115-32. doi: 10.1348/000709901158424

20. Stiernborg M, Bandaranayake R. Medical students' approaches to studying. Medical Teacher 1996;18:229-36. doi: 10.3109/01421599609034166

21. Biggs J, Kember D, Leung D. The revised two-factor Study Process Questionnaire: R-SPQ-2F. Br J Educ Psychol 2001;71:133-49. doi: 10.1348/000709901158433

22. Tetik C, Gurpinar E, Bati H. Students' learning approaches at medical schools applying different curricula in Turkey. Kuwait Med J 2009;41:311-6. doi:

23. Lawson R. The effect of viva assessment on students' approaches to learning and motivation Int Rev Soc Sci Human 2012;2:120-32.

24. Wickramasinghe D, Samarasekera D. Patterns of approaches to studying of pre-clinical, clinical and post graduate students 
from a setting in a developing country in Asia. Medical Teacher 2011b;33:338-41.

25. Samarakoon L, Fernando T, Rodrigo C, Rajapakse S. Learning styles and approaches to learning among medical undergraduates and postgraduates. BMC Med Educ 2013;13:42.. doi: 10.1186/1472-6920-13-42

26. Ozolins I, Hall H, Peterson R. The Student Voice: Recognising the hidden and informal curriculum in medicine Medical Teacher. 2008;30(6):606-11. doi: 10.1080/01421590801949933

27. Zhang J, Peterson R, Ozolins I. Student approaches for learning in medicine: What does it tell us about the informal curriculum? BMC Med Educ 2011;11(87):1-9. doi: 10.1186/1472-6920-11-87

28. Montecinos P, Pantoja M. The approach to learning in a traditional medical school. Medical Teacher 1991;13:305-10. doi: 10.3109/01421599109089910

29. Smith S, Miller R. Learning approaches: examination type, discipline of study, and gender. Educ Psychol 2015;25:43-53. doi: 10.1080/0144341042000294886

30. Gijbels D, Dochy F. Students' assessment preferences and approaches to learning: can formative assessment make a difference? Educa Stud 2006;32:401-11. doi: 10.1080/03055690600850354

31. Shah D, Yadav R, Sharma D, et al. Learning approach among health sciences students in a medical college in Nepal: a cross-sectional study. Adv Med Educ Pract 2016:137-43. doi: 10.2147/AMEP.S100968

32. Duff A. Approaches to learning: factor invariance across gender. Pers Individ Dif 2002;33:997-1010. doi: 10.1016/ S0191-8869(01)00208-2

33. Richardson T. Gender differences in responses to the approaches to studying inventory. Studies in Higher Education 1993;18:3-13. doi: 10.1080/03075079312331382418

34. Zhang L. University students' learning approaches in three cultures: An investigation of Biggs's 3P model. J Psychol 2000;134:37-55. doi: 10.1080/00223980009600847 